\title{
Menggunakan metode historis komparatif dalam penelitian psikologi
}

\author{
Nugraha Arif Karyanta ${ }^{1}$, Suryanto ${ }^{2}$, \& Wiwin Hendriani ${ }^{2}$ \\ ${ }^{1}$ Program Studi Psikologi Fakultas Kedokteran Universitas Sebelas Maret Surakarta \\ 2Program Doktor Psikologi, Fakultas Psikologi, Universitas Airlangga Surabaya
}

\begin{abstract}
Abstrak
Metode historis komparatif merupakan salah satu bagian dari pendekatan penelitian kualitatif yang masih jarang dilakukan dalam dunia psikologi di Indonesia. Tulisan berikut mencoba memaparkan nature dari pendekatan historis komparatif, mulai dari sudut pandang hingga tahap-tahap pelaksanaan penelitian dengan menggunakan metode tersebut. Tulisan ini membahas beberapa bidang psikologi yang telah menggunakan pendekatan historis komparatif dan menyuguhkan beberapa contoh penelitian dari hasil literatur review yang menggunakan pendekatan tersebut. Selain itu, artikel juga mendiskusikan secara mendalam kelemahan dan kelebihan dari pendekatan historis komparatif dalam penelitian psikologi di Indonesia.
\end{abstract}

Kata kunci: metode, kualitatif, historis komparatif, psikologi

\begin{abstract}
The comparative-historical method, as a qualitative research approach, remains rarely adopted in the field of psychological research in Indonesia. The following article will outline the nature of the comparative-historical approach in psychology, as a general perspective and as a step-by-step method for conducting research. It will also discuss various areas of psychological research characterized by a comparative-historical approach, and present a literature review of research examples that highlight its uses. The article further evaluates the weaknesses and strengths of the comparative-historical method as used in Indonesian psychological research.
\end{abstract}

Keywords: method, qualitative, historical-comparative, psychology

\section{Pendahuluan}

Penelitian kuantitatif seringkali dianggap dalam dunia psikologi sebagai lebih "ilmiah", obyektif, dan teliti daripada penelitian kualitatif (Simonton, 2003), hal ini mengakibatkan penelitian kualitatif pernah dipandang sebelah mata. Abidin (2006), misalnya, menyebutkan bahwa penelitian kualitatif bidang psikologi di Indonesia baru bermunculan setelah tahun 1990-an, itupun dengan jumlah yang masih jauh lebih sedikit dibandingkan penelitian kuantitatif. Hasil penelitiannya terhadap metode penelitian yang digunakan oleh mahasiswa S-1 dalam mengerjakan skripsi memperlihatkan bahwa mahasiswa yang menggunakan metode kualitatif di sebuah Fakultas Psikologi di Semarang berkisar pada 10 persen.

Meskipun demikian, perkembangan dunia psikologi ilmiah di Indonesia memperlihatkan tren yang positif dan semakin mengakui penelitian kualitatif sebagai metode yang dapat seiring sejalan dengan penelitian kuantitatif. Afiatin (1997) mengungkapkan bahwa kedua pendekatan tersebut memiliki kelemahan dan kelebihannya masingmasing, di mana pendekatan kuantitatif lebih menjelaskan kepada apa dan berapa tetapi kurang memberikan informasi tentang mengapa yang lebih menjadi domain bagi penelitian kualitatif, demikian juga bahwa pendekatan kuantitatif lebih menekankan pada hasil dari perhitungan statistik yang dilakukan, sedangkan proses suatu peristiwa atau kejadian tertentu lebih banyak terjawab dengan pendekatan kualitatif.

Penelitian kualitatif memiliki beberapa pendekatan untuk menjawab pertanyaan penelitian yang ada, dengan masing-masing karakteristik yang berbeda untuk berbagai pendekatan yang ada dalam metode penelitian kualitatif tersebut. Tulisan ini akan memberikan ulasan terhadap salah satu pendekatan dalam penelitian kualitatif, yakni penelitian historis komparatif. Penelitian historis komparatif merupakan salah satu pendekatan dalam genre penelitian kualitatif, termasuk yang jarang digunakan dan jarang mendapatkan perhatian dalam bidang psikologi bila dibandingkan dengan penelitian fenomenologi, studi kasus, grounded, analisis wacana, maupun etnografi. Jarangnya penggunaan penelitian ini terlihat misalnya terlihat dari artikel Somantri (2005) yang menyebutkan lima jenis penelitian kualitatif yang banyak dipergunakan: (1) observasi terlibat; (2) analisa percakapan; (3) analisa wacana; (4) analisa isi; dan (5) pengambilan data etnografis, dan sama sekali tidak menyebutkan metode historis komparatif dalam artikelnya tersebut. 
Disiplin ilmu yang banyak menggunakan penelitian historis komparatif di Indonesia adalah linguistik dengankajianlinguistik historis komparatif, lalu disiplin sosiologi dan antropologi. Penelusuran pada situs pencari Portal Garuda Indonesian Publication Index (IPI) pada 15 September 2019 dengan kata kunci "historis komparatif" misalnya menemukan 19 artikel di mana 15 berasal dari disiplin ilmu linguistik dan tidak ada yang berasal dari disiplin psikologi. Penelusuran pada situs Indonesia One Search (IOS) dari Perpustakaan Nasional menemukan 91 hasil untuk kata kunci "historis komparatif" dengan hasil yang lebih bervariasi, dengan lebih dari 80\% merupakan kajian linguistik, dan tidak satupun merupakan kajian psikologi. Hal ini menunjukkan bahwa metode historis komparatif merupakan metode yang masih asing dan jarang digunakan dalam riset psikologi di Indonesia.

\section{Sudut Pandang Penelitian Historis Komparatif}

\section{Definisi dan paradigma}

Neuman (2007) menyebutkan historis komparatif sebagai metode yang menempatkan waktu kesejarahan dan variasi antar budaya sebagai pusat pertanyaan penelitian, pengumpulan data, dan analisis data. Penggunaan metode ini memerlukan pengetahuan yang menyeluruh mengenai sejarah dan konteks budaya yang melingkupi seputar pertanyaan penelitian. Sementara itu, Babbie (2008) menyebutkan bahwa penelitian komparatif dan historis sebagai penyelidikan atas masyarakat (atau unit sosial lain) selama periode waktu tertentu dan dalam perbandingan satu sama lain. Metode ini berbeda secara substansial dengan metode-metode yang ada meskipun saling tumpang tindih dengan penelitian lapangan maupun penelitian lain yang bersifat unobstrusive seperti analisis isi maupun analisis atas data statistik yang ada.

Analisis komparatif historis berusaha menemukan pola umum yang muncul kembali dan bertahan di berbagai waktu dan tempat yang berbeda (Babbie, 2008). Lebih jauh dijelaskan bahwa analisis komparatif historis digunakan ketika fokus penelitian tidak terpaku dalam satu titik waktu tertentu, dan ketika perbandingan periode waktu diperlukan untuk lebih memahami perkembangan dan pengaruhnya pada bentuk-bentuk sosial.

Salah satu contoh yang terkenal atas penggunaan metode historis komparatif dalam penelitian psikologi adalah McClelland (1961) dengan penelitian mengenai achieving society, yang menguji dan mengembangkan teori mengenai pengaruh Need for Achievement atau motivasi berprestasi terhadap perkembangan ekonomi suatu masyarakat. McClelland (1961) melakukan serangkaian studi, yaitu: (1) studi atas budaya yang belum memiliki budaya baca; (2) studi atas negara-negara modern; dan (3) studi historis. Pada studi pertama, McClelland membandingkan motivasi berprestasi pada berbagai kultur yang belum memiliki budaya baca. Dalam studi ini estimasi atas motivasi berprestasi dilakukan dengan menggunakan cerita rakyat, sedangkan estimasi perkembangan ekonomi didapatkan dari presentase warga dewasa yang terlibat dalam aktivitas kewirausahaan penuh waktu. Studi pertama ini memberikan kesimpulan perkembangan ekonomi yang lebih maju pada budaya dengan motivasi berprestasi lebih tinggi.

Studi kedua mencakup perbandingan berbagai negara modern pada seputaran tahun 1925 dan 1950, menggunakan cerita anak pada bacaan di sekolah dasar untuk estimasi motivasi berprestasi, serta jumlah energi listrik yang diproduksi sebagai indeks pertumbuhan ekonomi. Perbandingan data pada dua periode tersebut memperlihatkan bahwa motivasi berprestasi yang tinggi mendahului pertumbuhan ekonomi, juga motivasi berprestasi merupakan faktor penyebab pertumbuhan ekonomi tersebut.

Studi ketiga sebagai studi historis memperlihatkan perbandingan antara Yunani Kuno, Spanyol di akhir Abad Pertengahan, Inggris dari masa Tudor hingga Revolusi Industri, dan Amerika dari Revolusi Industri hingga saat ini. Studi ini memberikan hasil bahwa tingkat motivasi berprestasi maksimum mendahului tingkat ekonomi maksimum. Secara umum dapat disimpulkan bahwa studi McClelland (1961) ini merupakan studi historis komparatif, yang mampu meneropong dan membangun argumentasi atas pengaruh motivasi berprestasi secara lintas budaya, lintas bangsa dan lintas waktu, hal yang akan sangat sulit dilakukan oleh metode penelitian lain.

\section{Kapan menggunakan metode historis kompa- ratif}

Neuman (2007) menyebutkan beberapa kondisi yang paling sesuai untuk dijawab menggunakan metode historis komparatif. Kondisi pertama adalah ketika peneliti ingin mencari tahu mengapa hasil sosial tertentu terjadi, misalnya mengapa pengaturan sosial tertentu terjadi dalam satu masyarakat dan tidak pada masyarakat yang lain dan mengapa suatu kebijakan tertentu muncul bukan kebijakan yang lain. Contoh dari bidang psikologi terkait kondisi ini dapat dilihat pada disertasi DellaMattera (2006) yang berjudul "A Historical Comparative Analysis of Preschool Policy Framework". Dalam penelitian ini, DellaMattera melakukan kajian atas kebijakan untuk pra-sekolah sebelum dan setelah gerakan No Child Left Behind (NCLB) dan Good Start Grow Smart (GSGS) di Amerika.

Situasi kedua ketika peneliti ingin membandingkan sebuah topik proses dan konsep sosial yang sama pada beberapa konteks budaya atau historis yang berbeda. Contoh situasi ini dapat dilihat pada disertasi Davis (2003) yang menggunakan metode 
historis komparatif dengan judul "Al-Qaeda and The Phinehas Priesthood Terrorist Groups with A Common Enemy and Similar Justifications for Terror Tactics". Penelitian ini membandingkan dua grup teror dari kelompok agama yang berbeda, yakni Al Qaeda dari Islam dan Phinehas Priesthood dari Kristen, untuk mencari persamaan dan perbedaan dari kedua kelompok tersebut. Hasil penelitian memperlihatkan beberapa persamaan yang kuat antara dua kelompok dalam berbagai hal, misalnya keyakinan bahwa mereka merupakan pilihan Tuhan, memiliki tujuan umum untuk memurnikan masyarakat pada titik tertentu, dan mereka cenderung terisolasi dari masyarakat pada umumnya.

Ketiga, makanala peneliti ingin menentukan apakah penjelasan "lama" atas fenomena sosial tertentu masih valid sejalan dengan perubahan dari waktu ke waktu. Penelitian dari Castillo (2011) menjadi contoh mengenai pertanyaan dalam skema ini, yaitu penelitian berjudul "A Comparative Historical Analysis of Post-War Moral Panics and the Construction of Youth From 1938 to 2011". Tujuan dari penelitian ini adalah untuk membandingkan munculnya dan perkembangan kepanikan moral terkait dengan hiburan yang menarik bagi kaum muda-seperti buku komik, lirik musik, internet, film, dan televisi-sejak 1938 hingga 2010 untuk lebih memahami cara kita mengonstruksi pandangan mengenai remaja dalam konteks kepanikan moral. Model Cohen tahun 1972 tentang perkembangan kepanikan moral digunakan untuk membandingkan reaksi terhadap hiburan yang menarik bagi kaum muda selama periode 50 tahun untuk menentukan apakah mereka mengikuti pola yang sama.

\section{Karakteristik penelitian komparatif historis}

Metode historis komparatif dapat memperkuat dan mengonseptualisasikan pembangunan teori, karena penggunaan konsep cenderung tidak terbatas pada satu waktu historis atau budaya. Karena itu, metode ini dapat didasarkan pada pengalaman orang-orang yang hidup dalam konteks budaya dan sejarah tertentu. Sebagai akibatnya, adalah tepat untuk membandingkan seluruh sistem sosial untuk melihat apa yang umum di masyarakat, apa yang unik, dan mempelajari perubahan sosial jangka panjang karena membawa keluar atau mengungkapkan hubungan antara faktor sosial yang berbeda.

Disertasi Cervenka (1997) merupakan salah satu contoh menarik dari bidang psikologi yang melakukan perbandingan dalam perkembangan psikologi pendidikan pada dua kultur berbeda yang mewakili timur dan barat, yakni antara Cina dengan Amerika Serikat. Penelitian tersebut menggunakan metode komparatif dan historis untuk menyelidiki perbedaan dan kesamaan psikologi pendidikan yang berkembang di Cina dan di Amerika, serta tingkat saling mempengaruhi antara psikologi pendidikan dalam dua negara tersebut. Cervenka melakukan penelusuran kesejarahan psikol ogi pendidikan di Cina dan Amerika, membaginya ke dalam pengaruh filsuf kuno dari tahun 500 sebelum Masehi hingga pada abad pertengahan, lalu abad pertengahan hingga masa post-renaissance, dan abad modern. Bagian akhir dari penelitian tersebut, sebagai konklusi, kemudian membandingkan filosofi Cina dengan barat; dan psikologi pendidikan Cina dengan psikologi pendidikan dari Amerika.

Mahoney dan Rueschemeyer (2003) menyebutkan tiga karakteristik dari studi historis komparatif. Pertama, penjelasan dan identifikasi konfigurasi kausal merupakan bagian krusial dalam studi historis komparatif. Argumen kausal merupakan bagian penting bagi analisis, sehingga proposisi kausal dipilih dan diuji secara hati-hati, karena itu analisis historis komparatif tidak memasukkan berbagai karya yang menolak atau menjauhkan diri dari analisis kausal. Sebagai contoh, penelitian yang menghindari analisis kausal karena lebih memilih pendekatan "interpretif" yang bertujuan untuk makna kultural dari perilaku manusia tidak termasuk dalam studi historis komparatif. Kedua, peneliti historis komparatif secara eksplisit menganalisis rangkaian historis dan memberi perhatian terhadap proses yang belum terungkap. Karena itu, analisis historis komparatif akan memasukkan struktur temporal dalam penjelasan mereka. Ketiga, penelitian historis komparatif adalah khas karena para praktisi terlibat dalam perbandingan yang sistematis dan kontekstual dari kasus-kasus yang serupa dan kontras. Pembandingan sistematis, tentu saja, sangat diperlukan mengingat minat analitik dalam analisis kausal.

Selain beberapa karakteristik tersebut, Lange (2013) menyebutkan kriteria mengenai unit analisis sebagai elemen penting bagi penelitian historis komparatif. Penelitian historis komparatif secara tradisional mengambil sudut pandang struktural dan menjelajahi proses pada tingkat meso dan makro, yaitu proses yang melibatkan beberapa individu dan memproduksi pola-pola relasi sosial. Tilly (1984) mendeskripsikan historis komparatif digunakan untuk menganalisa struktur dan proses besar, dan melakukan perbandingan yang sangat besar. Meskipun demikian, Lange (2013) mengungkapkan bahwa hal ini tidak menghalangi peneliti historis komparatif mengenali pentingnya dinamika individu, akan tetapi tetap mengaitkan dinamika tersebut dengan realitas struktural yang membentuk tin-dakan individu. Dalam hal ini, bahkan ketika menganalisis proses dalam level individual, peneliti historis komparatif tetap mempertahankan fokus struktural dan mempertimbangkan hubungan antara individu dengan struktur. Poin ini menjadi penting dalam kancah penelitian psikologi karena ketertarikan alamiah dari psikologi terhadap mekanisme psikis individual, yang dalam penelitian historis komparatif akan membandingkan pengaruh sosial secara temporal dari waktu ke waktu. 
Tabel 1

Beberapa Contoh Penelitian Historis Komparatif

\begin{tabular}{|c|c|c|c|}
\hline No & Peneliti \& Judul & Pertanyaan Penelitian & Sumber Data dan Analisis Data \\
\hline 1 & $\begin{array}{l}\text { DellaMattera, J. N. M. } \\
\text { (2006). A Historical } \\
\text { Comparative Analysis of } \\
\text { Preschool Policy } \\
\text { Frameworks. Disertasi. } \\
\text { Maine: The University of } \\
\text { Maine. }\end{array}$ & 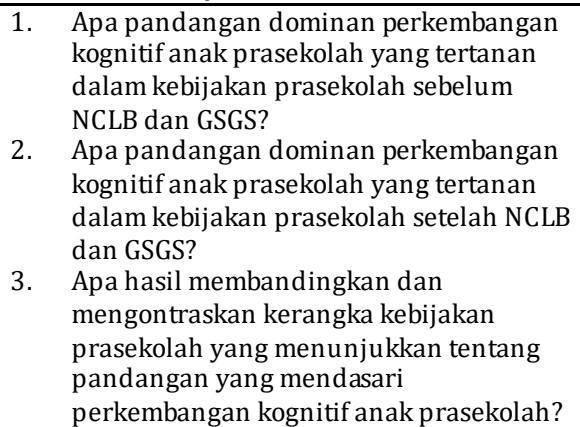 & $\begin{array}{l}6 \text { kerangka kebijakan prasekolah di Amerika } \\
\text { sebelum (2 kebijakan) dan sesudah (4 } \\
\text { kebijakan) NCLB dan GSGS. Multilevel } \\
\text { deductive coding process, mulai dengan } \\
\text { preliminary sort, lalu melakukan analisis } \\
\text { dengan membaca dan membaca ulang data, } \\
\text { melakukan kategorisasi dan koding, menca- } \\
\text { tat pola, kesenjangan, divergensi, baik pem- } \\
\text { buatan makna eksplisit maupun implisit, dan } \\
\text { menyimpan asumsi-asumsi. }\end{array}$ \\
\hline 2 & $\begin{array}{l}\text { Castillo, J. L. (2011). A } \\
\text { Comparative Historical } \\
\text { Analysis of Post-War Moral } \\
\text { Panics and the Construction } \\
\text { of Youth From } 1938 \text { to } \\
\text { 2011. Disertasi. Florida: } \\
\text { University of South Florida. }\end{array}$ & $\begin{array}{ll}\text { 1. } & \text { Apa pola kepanikan moral pasca perang } \\
\text { seputar buku komik (1950-an), lirik } \\
\text { dalam musik yang menarik bagi remaja } \\
\text { (1980), teknologi Internet awal (1990- } \\
\text { an), dan film dan televisi kontemporer } \\
\text { (2000-an)? } \\
\text { 2. Karakteristik apa yang menjadi perhatian } \\
\text { modern tentang tabu yang ditemukan } \\
\text { dalam film dan televisi yang menarik bagi } \\
\text { kaum muda dengan kepanikan moral } \\
\text { yang terjadi antara tahun } 1938 \text { dan } 2010 \\
\text { yang berfokus pada buku-buku komik, } \\
\text { lirik musik dalam musik yang menarik } \\
\text { bagi remaja, dan teknologi Internet awal? } \\
\text { 3. } \begin{array}{l}\text { Bagaimana kepanikan moral di atas } \\
\text { memengaruhi konstruksi modern remaja? }\end{array}\end{array}$ & $\begin{array}{l}\text { Untuk data komik menggunakan sumber } \\
\text { data primer termasuk majalah wanita } \\
\text { seperti Ladies Home Journal, McCall's, dan } \\
\text { Collier's, surat kabar termasuk New York } \\
\text { Times dan berbagai koran lokal, laporan } \\
\text { dewan kepresidenan, pidato pengukuhan, } \\
\text { dan dokumen Kongres. Yang terkait dengan } \\
\text { lirik musik tahun } 1980 \text {-an, peneliti meme- } \\
\text { riksa dokumen regulasi FCC, dokumen } \\
\text { dengar pendapat Kongres, dan berbagai } \\
\text { surat kabar harian. Untuk cyberporn tahun } \\
\text { 1990-an peneliti memeriksa berbagai surat } \\
\text { kabar harian, majalah nasional seperti Time, } \\
\text { undang-undang yang mencakup Undang- } \\
\text { Undang Telekomunikasi tahun } 1996 \text {, COPA, } \\
\text { dan CIPA, dokumen kongres, dan situs web } \\
\text { advokasi orang tua seperti cyberangels.org } \\
\text { dan missingkids.com. Analisis menggunakan } \\
\text { kerangka kepanikan moral dari buku Cohen } \\
\text { (1972) Fold Devils and Moral Panics. }\end{array}$ \\
\hline
\end{tabular}

3 Davis, D. W. (2003). Al-

Qaeda and The Phinehas

Priesthood Terrorist

Groups with A Common

Enemy and Similar

Justifications for Terror

Tactics. Disertasi. Texas

A\&M University.
1. Bagaimana menggunakan teori HRD untuk mempelajari kelompok teroris, membantu badan counterterrorist maupun anti-teroris mengalah kah ancaraman terorisme?

2. Apa elemen ideologis, historis dan organisasional yang datang dari sisi berseberangan dengan spektrum politik dan kultural?
Menggunakan dokumen terkait sejumlah 284 dokumen. Melakukan analisis persamaan (similarities) dan perbedaan (differences) terhadap 2 organisasi teror dari Islam (Al Qaeda) dan Kristen (Phineas Priesthood). Proses diawali dengan melakukan review singkat atas terorisme di abad 20 dan permulaan abad 21, kemudian melacak sejarah, budaya dan keyakinan dan fundamentalis Islam dan Kristen. Fokus kemudian dipersempit pada Al Qaeda dan Phineas Priesthood. Konteks HRD dari perilaku organisasi digunakan untuk memotret kesamaan dan perbedaan antara kedua kelompok teroris ini.

Data yang akan dianalisis berupa sinopsi ringkas dari: periode dan pelaku dalam timeline, biografi historis yang berfokus pada pemimpin wilayah, struktur pemerintahan, detail sejarah dan diskripsi transisi, sejarah dan diskripsi konflik domestik, konflik internasional, pemeriksaan detail bagaimana pemimpin dan pemerintah terlibat konflik, bagan yang mengidentifikasi ciri sifat kepribadian atau perilaku dari pemimpin dan pemerintah (secondary element). Menerapkan analisis historis kualitatif. Memeriksa menggunakan periode historis tertentu dimana Rusia mengalami konflik. Analisis akan mencakup penjelasan terperinci tentang transisi sosial / politik, pemeriksaan biografi singkat tentang kepemimpinan periode saat ini, dan riwayat 


\begin{tabular}{|c|c|c|c|}
\hline & & $\begin{array}{l}\text { manusia, sahih digunakan untuk menggali } \\
\text { bangsa tertentu. } \\
\text { 6. Apakah profiling perilaku nation-state } \\
\text { valid dari sisi metode? } \\
\text { 7. Dapatkah identifikasi homogoni perilaku } \\
\text { ini berkontribusi pada model yang lebih } \\
\text { mendetail untuk memprediksi tindakan } \\
\text { Rusia di masa mendatang? } \\
\text { 8. Dapatkah identifikasi perilaku ini } \\
\text { berkontribusi pada model yang lebih } \\
\text { mendetail untuk memprediksi tindakan } \\
\text { Rusia di masa mendatang? }\end{array}$ & $\begin{array}{l}\text { singkat tentang konflik terpilih yang diha- } \\
\text { dapi negara, baik internasional maupun } \\
\text { domestik. Kemudian akan dilakukan profil- } \\
\text { ing dari data yang didapatkan. }\end{array}$ \\
\hline 5 & $\begin{array}{l}\text { Rollins, M. (2017). } \\
\text { Psychopathy And } \\
\text { Narcoterrorism: A } \\
\text { Comparative Historical } \\
\text { Analysis of Pablo Escobar } \\
\text { and “El Chapo" Guzman. } \\
\text { Thesis. California: California } \\
\text { Baptist University. }\end{array}$ & $\begin{array}{l}\text { Menyediakan referensi komparatif psikologis untuk } \\
\text { mengerti patologi yang mempengaruhi perilaku } \\
\text { kriminal psikopati. Memeriksa konteks historis dan } \\
\text { psikologis narco-culture. }\end{array}$ & $\begin{array}{l}\text { Sumber data adalah artikel terpilih dari } \\
\text { jurnal: Journal of Abnormal Psychology, } \\
\text { Journal of Forensic Psychiatry and Psych- } \\
\text { ology, The Journal of Personality Disorder, } \\
\text { The American Journal of Psychiatry. Data } \\
\text { untuk Pablo Escobar dan El Chapo tidak } \\
\text { dijelaskan, tampaknya didapatkan dari data } \\
\text { sekunder. Melakukan analisis atas Pablo } \\
\text { Escobar dan El Chapo dengan data sekunder, } \\
\text { tidak menyebutkan data primer dalam } \\
\text { metode meskipun mungkin ada. Melakukan } \\
\text { profiling. }\end{array}$ \\
\hline 6 & $\begin{array}{l}\text { Cervenka, H. L. (1997). A } \\
\text { Comparative Study of the } \\
\text { Development of } \\
\text { Educational Psychology in } \\
\text { China and America. } \\
\text { Disertasi. Virginia: West } \\
\text { Virginia University. }\end{array}$ & $\begin{array}{l}\text { Tujuan perbandingan ini untuk menemukan apakah } \\
\text { psikologi barat dan psikologi Asia khususnya } \\
\text { psikologi pendidikan Cina dan Amerika secara } \\
\text { fundamental berbeda dan tidak bisa bersatu, atau } \\
\text { ada hal yang umum diantara kedua psikologi } \\
\text { pendidikan tersebut. }\end{array}$ & $\begin{array}{l}\text { Tidak menyebutkan sumber data secara } \\
\text { khusus. Data yang dianalisis adalah data } \\
\text { sekunder yang ditata secara historis dari } \\
\text { tahun } 500 \text { sebelum Masehi hingga pada abad } \\
\text { pertengahan, lalu abad pertengahan hingga } \\
\text { masa post-renaissance, dan abad modern, } \\
\text { mengenai psikologi pendidikan baik di } \\
\text { Amerika maupun Cina. Menggunakan pen- } \\
\text { dekatan personalistik dan naturalistik dalam } \\
\text { analisis. Personalistik karena adanya } \\
\text { capaian dan kontribusi masif dari beberapa } \\
\text { individu. Tidak ada bagian khusus mengenai } \\
\text { proses penelitian, meskipun disebutkan } \\
\text { menggunakan perbandingan persamaan dan } \\
\text { perbedaan (similarities and difference). }\end{array}$ \\
\hline
\end{tabular}

\section{Metodologi Penelitian Historis Komparatif}

\section{Tipe-tipe penelitian historis komparatif}

Skocpol dan Somers (1980) menggambarkan tiga tipe penelitian historis komparatif. Pertama adalah "parallel comparative" yang mencoba memvalidasi hipotesis atau teori dengan lintasan kesejarahan. Dalam psikologi sosial, salah satu aplikasi klasik terkait tipe paralel komparatif ini adalah penelitian Janis (1982) mengenai groupthink, di mana Janis memperlihatkan fenomena groupthink mempengaruhi proses pengambilan keputusan yang dilakukan dalam konteks krisis internasional yang penting. Dalam bukunya tersebut, Janis menunjukkan berbagai bencana yang terjadi sebagai akibat dari proses groupthink dalam pengambilan keputusan pada kebijakan luar negeri Amerika Serikat, dan menggunakan beberapa peristiwa sejarah untuk memvalidasi konsep tersebut, seperti kegagalan dalam antisipasi penyerangan Jepang terhadap Pearl Harbor (1941), penyerangan Teluk Babi (1961), dan prosekusi atas Perang Vietnam (1964-1967).

Kedua, "contrast-oriented comparative history" menggambarkan kontras dan menjaga integritas historis pada tiap kasus yang dibidik. Berbeda dengan tipe pertama yangmenggunakan kasus untuk mendukung teori, tipe ini menggunakan historis komparatif untuk meli hat keunikan fitur tiap kasus yang didiskusikan untuk menunjukkan bagaimana gambaran unik ini mempengaruhi proses sosial yang terjadi secara umum. Kemp dan Strongman (1995) misal nya melakukan anal isis atas pandangan zaman kuno dan zaman pertengahan atas kemarahan (anger)-kemenjadian, sebab-sebab, dan kontrol atas kemarahan tersebut, dan mengomparasikan dengan pandangan modern atas kemarahan dan praktek manajemen kemarahan.

Ketiga adalah "makro causal analysis" yang menggunakan analisis makro-kausal, menyerupai analisis statistik, yang memanipulasi kelompok kasus dalam mengendalikan sumber variasi untuk membuat kesimpulan kausal ketika data kuantitatif tersedia tentang sejumlah besar kasus. Contoh dalam lapang psikologi adalah penelitian dari McGuire (1976) yang mengumpulkan sejumlah besar data terkait human related area files (HRAF) dan melakukan berbagai analisis korelasional atas proporsi pesohor, pimpinan atau orang-orang terkenal dari beberapa periode waktu, wilayah, dan bidang yang berbeda.

Meskipun memiliki logika dan tujuan yang lebih dekat dengan penelitian kualitatif, peneliti dapat menggunakan data-data kuantitatif untuk 
menjadi suplemen atas data dan analisis kualitatif dalam penelitian historis komparatif ini, meskipun hal tersebut tidak menjadi tuntutan mutlak (Yuginovich, 2000). Tujuan penelitian historis komparatif bukanlah untuk mengembangkan jawaban semata, tetapi memberikan jawaban yang spesifik terkait orang, tempat dan waktu tertentu (Neuman, 2007).

\section{Sumber data penelitian historis komparatif}

Neuman (2007) mengungkapkan beberapa sumber data dalam penelitian historis komparatif, meliputi data primer, data sekunder, catatan yang masih berlangsung (running records), dan rekoleksi.

1. Data primer dapat berupa surat, diari, koran, majalah, novel, artikel tentang berbagai macam hal terkait, foto-foto, dan berbagai macam hal lain dari masa lalu yang sekarang masih tertinggal. Data-data ini dapat ditemukan di arsip tertentu, koleksi pribadi, museum, kloset keluarga, dan lain sebagainya. Dokumen dan obyek yang ada hari ini akan menjadi sumber data bagi penelitian historis komparatif masa depan. Dokumen tertulis baik yang dipublikasikan maupun tidak dipublikasikan biasanya merupakan tipe data primer yang paling penting.

2. Data sekunder dalam penelitian historis komparatif adalah tulisan dari sejarahwan yang meneliti tentang suatu bidang tertentu sebagai data primernya. Hal ini seringkali harus dilakukan sebagai bagian awal untuk mengerti permasalahan tertentu, atau karena keterbatasan praktis yang didapati oleh peneliti.

3. Catatan yang masih berlangsung (running records) terdiri dari file atau dokumen statistik yang dimiliki oleh perusahaan. Contoh dari tipe data ini adalah file dari Kantor Urusan Agama yang mencatat pernikahan dari sejak jaman dahulu kala hingga sekarang.

4. Rekoleksi (recollections) merupakan catatan atau kata-kata dari individu mengenai kehidupan mereka sebelumnya atau pengalaman yang mereka milikiyang didasarkan dari ingatan. Hal ini dapat dalam bentuk riwayat hidup, otobiografi, atau wawancara. Perlu menjadi catatan bahwa ingatan sangat mudah terdistorsi, berbeda dengan sumber data primer misalnya.

\section{Tahap Penelitian Historis Komparatif}

Neuman (2007) mengungkapkan bahwa penelitian historis komparatif tidak memiliki serangkaian tahapan yang kaku, dan biasanya tidak menggunakan teknik kompleks yang khusus. Berikut beberapa tahap yang dianjurkan oleh Neuman untuk melakukan penelitian tersebut.

\section{Konseptualisasi topik dan kondisi penelitian}

Peneliti memulai dengan mengenali secara dekat dengan seting dan melakukan konseptualisasi atas obyek penelitian. Peneliti dapat mulai dengan model atau konsep awal dan menerapkannya dal am konteks tertentu. Konsep yang dimiliki memang akan memiliki asumsi atau organisasi kategoris tertentu yang akan memandu pencarian bukti-bukti. Hal ini dilandasi oleh keyakinan Neuman bahwa sebuah penelitian yang serius tidak dapat dilakukan tanpa kerangka asumsi, konsep atau teori. Jika peneliti belum cukup akrab dengan era sejarah atau seting komparatifnya, peneliti dapat melakukan orientation reading, yaitu membaca beberapa karya umum yang terkait.

\section{Memetakan bukti}

Langkah selanjutnya adalah memetakan dan mengumpulkan data melalui kerja bibliografis ekstensif. Pertanyaannya adalah, di mana menemukan informasi atas topik bersangkutan? Sumber-sumber pustaka, literatur ilmiah, koran, museum, catatan organisasi dan berbagai sumber informasi lain dapat menjadi sumber data yang diperlukan. Dalam langkah ini, peneliti biasanya menghabiskan berminggu-minggu waktu di perpustakaan, mengunjungi beberapa perpustakaankhusus, dan membaca puluhan atau ratusan buku dan artikel. Peneliti kemudian akan menyesuaikan konsep awal, pertanyaan atau fokus berdasarkan apa yang dia temukan, dan mempertimbangkan beberapa laporan penelitian pada beberapa level analisis.

\section{Mengevaluasi kualitas bukti}

Peneliti perlu mengumpulkan bukti dengan pertanyaan: bagaimana relevansi bukti ini dengan pertanyaan penelitian yang timbul? Seberapa akurat dan kuat bukti yang didapatkan? Apakah ada bagian informasi atau orangyang hilang atau tidak terwakili dalam bukti-bukti tersebut? Peneliti historis komparatif membaca bukti untuk tiga hal: kerangka konseptual implisit, detail-detail tertentu, dan generalisasi empiris.

\section{Mengorganisasi bukti}

Dalam mengorganisasi data, peneliti menggunakan insight teoritis untuk menstimulasi cara baru mengorganisasi data dan mendapatkan pertanyaan baru terhadap bukti-bukti. Apakah terdapat pola yang nampak ketika me-review materi-materidi atas? Peneliti mulai analisis awal dengan memperhatikan generalisasi atau tema sederhana yang mungkin nampak. Dalam tahap ini, perlu diperhatikan interaksi antara data dan teori, yang berarti bahwa peneliti mencoba memeriksa permukaan dari bukti-bukti yang ada untuk mengembangkan konsep baru dengan melakukan evaluasi secara kritis terhadap bukti- 
bukti atas dasar teori yang ada. Misalnya, Neuman (2008) mencontohkan ketika peneliti membaca banyak bukti tentang aksi protes. Analisis awal mengorganisasikan bukti atas tema yang ada: orangorang yang aktif dalam aksi protes berinteraksi satu sama lain dan mengembangkan makna kultural bersama. Dia kemudian meneliti teori mengenai kultur dan aksi, kemudian membangun konsep baru: "subkultur aksi oposisional". Peneliti kemudian memeriksa bukti-bukti dengan konsep ini.

\section{Sintesa}

Langkah selanjutnya adalah mensintesakan bukti. Peneliti akan ketika semua bukti-bukti sudah berhasil dikumpulkan, peneliti memperhalus konsep yang dimiliki, dan mencari model eksplanatoris umum. Peneliti melihat pola selama rentang waktu atau antar unit, dan mencari persamaan (similarities) dengan perbedaan (differences) melalui analogi. Peneliti mengorganisasi peristiwa yang berbeda dalam sekuen-sekuen dan mengelompokkan untuk menciptakan gambaran besar. Kemudian dikembangkan penjelasan untuk menyatukan konsep dan bukti dalam satu kesatuan. Peneliti lalu membaca ulang catatan yang ada dan menyortirnya untuk mengorganisasikan skema.

\section{Menulis laporan}

Bagian ini adalah upaya menuliskan laporan yang ada, metode yang digunakan dan temuan dalam penelitian. Penulisan laporan merupakan kunci, merangkaikan bukti-bukti yang didapatkan dengan penjelasan yang sesuai akan membuat penelitian historis komparatifmenjadi bernilai tinggi atau tidak. Yuginovich (2000) mengemukakan 10 hal yang perlu diperhatikan ketika menulis laporan historis komparatif, yakni: (1) Sekuen. Peneliti historis komparatif harus peka dengan urutan waktu atas peristiwa atau kejadian, dan menempatkan serangkaian peristiwa untuk menggambarkan proses tersebut; (2) Komparasi. Pembandingan persamaan (similiraties) dan perbedaan merupakan inti dalam penelitian historis komparatif. Perbandingan harus secara implisit dilakukan, dan mencakup persamaan dan perbedaan; (3) Kontingensi. Penelitiakan seringkali mendapati bahwa suatu kejadian atau tindakan tertentu tergantung atau dikondisikan oleh orang lain. Menggarisbawahi bagaimana suatu perilaku dipengaruhi oleh orang lain atau peristiwa tertentu merupakan bagian kritis untuk memberikan makna secara tepat; (4) Asal (origin) dan konsekuensi. Peneliti historis komparatif akan melacak kejadian, tindakan, pengaturan atau keanggotaan dalam organisasi sosial tertentu sesuai dengan waktu pada saat itu atau konsekuensinya sesuai dengan periode waktu tertentu; (5) Kepekaan atas makna yang tidak kompatibel. Makna berbeda dan berubah setiap waktu dan bervariasi dalam budaya yang berbeda. Peneliti historis komparatif harus bertanya kepada diri sendiri apakah kata atau kategori sosial tertentu memiliki makna yang berbeda sepanjang berbagai waktu tertentu; (6) Generalisasi yang terbatas. Generalisasi berlebihan selalu merupakan masalah potensial dalam penelitian historis komparatif. Beberapa peneliti mencari penjelasan yang kaku dalam menjelaskan historis komparatif. Sebaliknya mereka memenuhi syarat pernyataan dan menghindari penentuan yang ketat; (7) Asosiasi. Konsep dari asosiasi digunakan dalam semua bentuk penelitian sosial. Sebagaimana dalam area lain, peneliti historis komparatif akan mengidentifikasi faktor yang muncul bersaman dalam tempat dan waktu tertentu; (8) Sebagian dan keseluruhan (part and whole). Penting untuk menempatkan kejadian dalam konteks secara tepat. Penulis historis komparatif akan memberikan kaitan antara bagian, proses, organisasi atau kejadian dan konteks lebih besar di mana mereka didapatkan; (9) Analogi. Penggunaan analogi dapat berguna. Meskipun demikian, penggunaan secara berlebihan atau analogi yang tidak tepat akan berbahaya; dan (10) Sintesis. Peneliti historis komparatif seringkali mensintesakan berbagai kejadian dan detail untuk memberikan gambaran yang menyeluruh. Sintesis berasal dari merajut bersamaan berbagai generalisasi dan interpretasi ke dalam tema utama yang koheren.

\section{Penelitian Historis Komparatif dalam Psikologi}

Pendekatan berbasis kesejarahan merupakan pendekatan yang jarang digunakan dalam bidang psikologi di Indonesia, meskipun cukup lama dilakukan dalam bidang psikologi.Simonton (2003), misalnya, menunjukkan bahwa psikolog dalam berbagai kesempatan telah menggunakan referensi informal dari peristiwa sejarah dan kepribadian untuk memberikan ilustrasi dari prinsip tertentu atau untuk membangun argumen, seperti misalnya yang dilakukan oleh William James (1880) salah satu tokoh sentral dalam psikologi modern. Elms (1998) mengungkapkan bahwa Freud telah menggunakan peristiwa masa lalu yaitu interpretasi psikoanalitik atas hidup dan karya dari Leonardo da Vinci. McGuire (1976) memberikan contoh mengenai beberapa pionir dalam penelitian psikologi yang menggunakan metode historis komparatif, diantaranya Sorokin yang mencoba untuk menguji dinamika kultural dengan menggunakan data historis lebih dari dua ribu tahun untuk memperlihatkan bahwa budaya dari waktu ke waktu merefleksikan pandangan hidup dominan.

Meskipun demikian, tidak serta merta seluruh pendekatan berbasis kesejarahan akan digolongkan dalam metode historis komparatif. Sebagai contoh, Simonton (1998) menyebutkan metode psychobiography dan psychohistory yang menggunakan data kesejarahan meskipun merupakan aktivitas keilmuan yang mulai dengan data historis, namun mengaplikasikan analisis kualitatif untuk mengonfirmasi pertanyaan idiografis tentang 
individu atau kejadian tertentu (Elms, 1998). Simonton (1998) memberikan contoh karya klasik dari Erik Erikson yang menulis tentang Mahatma Gandhi dan Martin Luther. Erikson secara jelas menunjukkan bahwa tujuan dari tulisan tersebut adalah untuk melihat dasar idiosinkrasis dari tiap pemimpin tersebut, dan tidak untuk mempelajari bagaimana bentuk kepemimpinan tertentu bekerja secara umum. Hal ini tentu berbeda dengan karakteristik metode historis komparatif sebagaimana diungkapkan oleh Lange (2013), di mana secara umum metode historis komparatif lebih berminat terhadap pertanyaan nomotetik daripada pertanyaan idiografik.

Metode yang paling dekat dengan historis komparatif yang banyak digunakan dalam disiplin psikologi barangkali adalah historiometri yang didefinisikan oleh Simonton (1998) sebagai: serangkaian metode di mana arsip data historis atas individu dan peristiwa menjadi subjek bagi analisis kuantitatif untuk menguji hipotesis nomotetik atas pikiran, perasaan dan tindakan manusia. Baik historis komparatif maupun historiometri sama-sama menggunakan data kesejarahan, biasanya menguji hipotesis nomotetik, maupun menggunakan beberapa kasus secara bersamaan (multiple cases). Meskipun demikian, pendekatan historiometri adalah pada analisis kuantitatif, berbeda dengan historis komparatif yang lebih memberikan penekanan pada studi kualitatif, walaupun historis komparatif juga dapat menggunakan data kuantitatif sebagai suplemen atas data kualitatif. Tidak mengherankan apabila beberapa penelitian bidang psikologi seperti studi McClelland The Achieving Society dapat dianggap sebagai penelitian historis komparatif (McGuire, 1976) maupun penelitian historiometri (Simonton, 1998; 2003).

Simonton (2003) mengungkapkan berbagai bidang psikologi menggunakan pendekatan berbasiskan kesejarahan untuk mendapatkan kesimpulan maupun mendukung argumen dan hipotesis yang dibangun. Dalam bidang psikologi kognitif, salah satu tokoh yang disebut oleh Simonton (2003) adalah Neiser (1981), yang membandingkan percakapan terekam dalam skandal "Watergate" Gedung Putih dengan kesaksian Senator John Dean mengenai percakapan tersebut, untuk mempelajari bagaimana fungsi memori dalam setting alamiah. Dalam bidang psikologi perkembangan, McGuire (1976) dan Simonton (2003) menyebut Quetlet (1968; dalam Simonton, 2003) yang memiliki ketertarikan relasi antara usia dan kinerja. Sejak saat itu telah banyak peneliti lain yang menggunakan topik penelitian yang sama (Raskin, 1936; Lehman, 1953; Dennis, 1966, Schulz \& Curnow 1988, Ohlsson, 1992; dalam Simonton, 2003). Dalam bidang psikologi diferensial Simonton (2003) menyebutkan bahwa sejak penelitian klasik Galton (1869), para psikolog sering menganalisis data historis untuk menguji perbedaan individual dalam kemampuan intelektual (Woods 1906, Thorndike 1936). Di antara yang paling inova- tif dari penelitian ini adalah estimasi Terman (1917) dari skor IQ untuk Francis Galton, perhitungan yang didasarkan pada prestasi masa kecil Galton. Bidang psikologi abnormal diungkapkan oleh Simonton (2003) sering diramaikan oleh kontroversi seputar capaian prestasi tinggi dari individu berprestasi tinggi tetapi tidak sehat mental atau kontroversi mengenai "mad genius".

Bidang psikologi yang paling berpotensi dan paling banyak menggunakan metode historis komparatif barangkali adalah psikologi sosial. Beberapa contoh berikut memperlihatkan bagaimana metode historis komparatif berfungsi memecahkan berbagai permasalahan dalam bidang psikologi sosial yang akan sulit diteliti menggunakan metode lain. Studi mengenai dampak peristiwa historis terhadap kondisi mental dan perilaku individu merupakan tema yang tepat untuk dipecahkan menggunakan metode historis komparatif. Hal ini karena hampir tidak mungkin untuk menciptakan replikasi atas kondisi historis yang telah terjadi baik di dunia nyata maupun di laboratorium, baik atas alasan praksis maupun etis. Sebagai contoh adalah penelitian dari Boor (1981) dan Boor dan Fleeming (1984) yang melihat pengaruh pemilihan presiden terhadap tindakan bunuh diri dan tindakan fatal lain. Contoh lain adalah penelitian dari Janis (1982) sebagaimana telah diungkap di atas mengenai proses groupthink yang mempengaruhi proses pengambilan keputusan yang digunakan para pemimpinan pada beberapa krisis internasional penting.

Simonton (1998; 2003) mengungkapkan beberapa cakupan lain atas metode historis dalam bidang psikologi. Riset dalam bidang sikap dan perubahan sikap misalnya menggunakan metode ini untuk menganalisis repeated exposure effect dalam pemilihan presiden Amerika (Grush, 1980). Demikian juga dengan penelitian pada bidang kepribadian otoritarian (Doty, dkk. 1991; McCann 1999) yang menggunakan data historis untuk memperlihatkan bagaimana otoritarianisme muncul sebagai respon terhadap ancaman dari luar (external threat). Cakupan lain misal dalam isu agresi memperlihatkan penelitian dari Phillips (1986) yang melihat apakah bunuh diri sebagiannya mendapatkan pengaruh dari kekerasan yang ditampilkan di media massa. Di bidang lain Simonton (2003) juga mencatat penggunaan statistik olahraga untuk meneliti efek fasilitasi sosial (Triplett, 1898).

\section{Hasil literature review}

Pencarian terhadap karya ilmiah dalam bidang psikologi di Indonesia yang menggunakan pendekatan historis komparatif dilakukan dengan melakukan pencarian di Indonesia One Search (IOS) dari Perpustakaan Nasional Republik Indonesia dan di Indonesia Publication Index (IPI). Hasil penelusuran tidak mendapatkan penelitian yang menggunakan metode tersebut dalam disiplin psikologi. Penelusuran dilanjutkan dengan melakukan 
pencarian pada web journal ProQuest pada 21 Juli 2018. Hasil penelusuran mendapatkan enam judul yang memenuhi kriteria penulis, yakni menggunakan pendekatan historiskomparatif dan berasal dari disiplin ilmu psikologi. Tabel 1 memperlihatkan hasil review dari penelitian tersebut.

Literature review yang dilakukan menghasilkan beberapa kesimpulan. Pertama, penulisan hasil penelitian yang menggunakan pendekatan historis komparatif tidakmenggunakan standar tertentu yang seragam. Hal ini mungkin terkait dengan nature dari penelitian kualitatif yang memerlukan fleksibilitas untuk mendapatkan hasil yang optimal. Meskipun demikian, beberapa penelitian tidak menunjukkan langkah yang jelas dalam proses yang dilakukan, baik dari sisi sumber data maupun dari sisi proses pelaksanaan penelitian yang dilakukan. Artikel 1 dan 2 merupakan artikel yang cukup jelas menunjukkan sumber data yang digunakan dalam penelitian tersebut pada bagian metode penelitian. Selebihnya tidak mendedikasikan diri untuk menjelaskan karakteristik dari sumber data yang digunakan.

Kedua, erdapat berbagai ragam yang cukup luas ketika seorang peneliti mengungkapkan diri menggunakan penelitian historis komparatif. Artikel 1 dan 2 secara jelas mengungkapkan menggunakan sumber data primer, termasuk kriteria yang diberikan terhadap sumber data tersebut. Artikel 3 hanya menuliskan sejumlah sekiandokumen yang dianalisis tapi tidak menunjukkan apa saja dokumen tersebut. Artikel 4 mengungkapkan menganalisis sinopsis atau deskripsi ringkas mengenai suatu tema, tetapi tidak dijelaskan secara detail. Artikel 5 menyebutkan sumber sekunder tertentu tapi tidak cukup spesifik. Artikel 6 sama sekali tidak menyinggung mengenai sumber data dari penelitian tersebut dalam bagian metode penelitian. Hal ini mungkin terkait perspektif yang diterakan atas penelitian historis komparatif, mungkin ada penelitian yang secara ketat menggunakan metode tertentu dari awal sampai akhir, tetapi ada yang menggunakan istilah historis komparatif sebagai cara analisis atau cara kepenulisan saja.

Ketiga, dari berbagai keragaman yang ada di antara artikel yang berhasil di-review, terdapat kesamaan dalam melakukan analisis, yaitu menggunakan analisis persamaan dan perbedaan, atau melacak persamaan dan perbedaan di antara subjek yang sedang dianalisis, atau melacak pola-pola tertentu yang ada.

Keempat, dalam artikel yang didapatkan, tidak dijumpai ada penelitian historis komparatif yang menggunakan pendekatan kuantitatif baik sebagai unsur utama maupun sebagai pendukung. Dari keenam studi historis komparatif ini semuanya berbasiskan kualitatif, tidak ada yang menggunakan model kuantitatif seperti yang ditunjukkan oleh McGuire (1976).

\section{Kelemahan dan Kelebihan Penelitian Historis Komparatif dalam Psikologi}

Pendekatan historis komparatif masih belum mendapatkan tempat dalam penelitian psikologi di Indonesia. Bagian berikut ini akan mengulas beberapa kelemahan dan kelebihan yang dimiliki oleh metode penelitian ini, untuk melihat kemungkinankemungkinan penggunaan metode ini di Indonesia, serta masa depan pendekatan historis komparatif dalam pengembangan keilmuan psikologi di Indonesia.

\section{Kelemahan}

Penelitian historis komparatif sebagai pendekatan yang lebih bersifat kualitatif (Neuman, 2007; Babbie, 2008) tampaknya masih dipertanyakan kesahihannya untuk memeriksa beberapa fenomena dalam bidang psikologi. Selain kesangsian terhadap metode kualitatif secara umum, dasar dan tahap penggunaan metode historis komparatif masih menyisakan berbagai pertanyaan sehingga menyulitkan dalam penatalaksanaan metode ini. Masalah selanjutnya terkait dengan karakteristik data yang disediakan oleh pendekatan historis komparatif ini. Simonton (2003) misalnya mengungkapkan bahwa data historis seringkali tidak sesahih data yang didapatkan dari penelitian konvensional. Seringkali catatan yang ada mengandung gap informasi atau eror yang dapat mengontaminasi analisis.

Hal lain yang menjadi concern dan bagian dari keraguan barangkali adalah posisi historis komparatif dalam perbincangan antara penelitian kuantitatif dan penelitian kualitatif. Penelitian historis komparatif meskipun sebagian besar ahli (Neuman, 2007; Babbie, 2008) meletakkannya sebagai bagian dari penelitian kualitatif, tetapi penggunaan aspek kuantitatif juga diperbolehkan baik sebagai unsur untuk mendukung penelitian maupun sebagai aspek utama untuk mendiskusikan permasalahan yang dibahas. Berbagai pendekatan kualitatif dalam kancah psikologi yang banyak digunakan biasanya memiliki sudut pandang "interpretif" yang sangat subyektif dari sisi partisipan penelitian, berupaya untuk memahami sudut pandang dari sisi partisipan, dan karena itu tidak memiliki keinginan untuk melihat unsur kausalitas antar variabelnya. Sedangkan beberapa ahli dalam bidang historis komparatif, seperti Mahoney dan Rueschemeyer (2003) misalnya, memasukkan proposisi kausalitas sebagai karakteristik inti dari pendekatan historis komparatif.

\section{Kelebihan}

Mengutip Babbie, DellaMattera (2006) mengungkapkan keuntungan dari penggunaan metode historis komparatif ini, diantaranya adalah sifat unobstrusive dari pengukuran historis komparatif, yang memberikan kesempatan untuk meneliti 
perilaku sosial tanpa mempengaruhi prosesnya. Demikian pula Simonton (2003) mengungkapkan sifat unobstrusive dan non-reactive dari data kesejarahan. Selain tidak memengaruhi proses penelitian, data yang digunakan dalam penelitian historis komparatis berasal dari dunia nyata (dibandingkan dengan data dari laboratorium), sehingga tidak diragukan aplikasi dari data tersebut. Keuntungan lain dari data kesejarahan adalah kemampuannya untuk membantu peneliti menelusur perkembangan bentuk sosial tertentu dalam berbagai rentang waktu (DellaMattera, 2006). DellaMattera (2006) juga menunjukkan bagaimana data kesejarahan dapat digunakan untuk membandingkan proses perkembangan dan menemukan pola dari waktu ke waktu; beberapa memiliki sifat evolusioner yang linier, sedangkan beberapa yang lain bersifat siklikal. Hal ini merupakan karakteristik khas dari data kesejarahan dibandingkan dengan data konvensional yang kebanyakan hanya mampu menangkap sebuah fenomena dalam satu konteks waktu. Simonton (2003) mengungkapkan bahwa data sejarah memiliki informasi penting yang memiliki makna praktis sangat besar untuk peneliti berhubungan dengan isu dan problem penting dalam dunia nyata. Salah satu bagian paling penting misalnya data mengenai kekerasan, di mana selain mempelajari faktor yang melatarbelakangi bunuh diri dan berbagai bentuk agresi personal lain (Anderson \& Anderson, 1984; Phillips \& Hensley, 1984, Miller, dkk., 1991), psikolog memiliki andil besar dalam memahami akar psikologis dari perang dan berbagai bentuk kekerasan kolektif lain (Winter, 1993; Suedfeld \& Bluck, 1998). Metode penelitian lain akan kesulitan dalam memberi luasan data seperti yang dimiliki oleh pendekatan historis komparatif, belum lagi kaitan dengan etika penelitian yang akan menentang tindak kekerasan nyata terhadap partisipan penelitian.

Keuntungan berikutnya dari penggunaan pendekatan historis komparatif adalah aspirasi psikologi yang menginginkan pengetahuan ilmiah yang betul-betul universal. Dengan kata lain, teori dan temuan dari ilmu psikologi harus dapat digunakan untuk semua umat manusia, bukan hanya pada subset homo sapiens yang kebetulan hidup dalam waktu yang sama dengan peneliti (Simonton, 2003). Sebaliknya, catatan kesejarahan memiliki informasi mengenai perilaku manusia dalam ragam yang teramat kaya atas budaya dan periode historis. Hal ini membuat peneliti mampu menentukan apakah satu temuan bisa melakukan klaim atas status crossculturalatau bahkan transhistorical.

\section{Kesimpulan: Masa Depan Penelitian Historis Komparatif Psikologi Indonesia}

Meskipun penelitian historis komparatif belum setenar berbagai pendekatan lain di Indonesia, beberapa argumentasi di atas menunjukkan bahwa metode ini telah cukup lama digunakan dalam dunia psikologi dan memberikan kontribusi penting (Simonton, 2003; McGuire, 1976). Pendekatan kualitatif, meskipun masih tertinggal dibandingkan pendekatan kuantitatif, memiliki percepatan yang tinggi dipandang dari mulai cukup banyak penelitian dari bidang psikologi yang menggunakan pendekatan tersebut, atau juga posisi mata kuliah metode penelitian kualitatif pada berbagai perguruan tinggi yang dulunya hanya mata kuliah pilihan, sekarang menjadi mata kuliah wajib, sejajar dengan metode penelitian kuantitatif. Meskipun penulis belum berhasil menemukan penelitian dalam disiplin ilmu psikologi di Indonesia yang menggunakan metode historis komparatif, perkembangan dalam metode penelitian kualitatif secara keseluruhan tersebut tampaknya akan mendorong penggunaan metodemetode penelitian lain yang belum umum digunakan seperti penelitian historis komparatifini.

Meskipun demikian, masih terdapat berbagai kendala untuk melaksanakan penelitian dengan menggunakan metode ini di Indonesia. Hal ini karena masih banyak perbedaan di antara para ahli tentang penggunaan metode ini dalam kancah psikologi. Di luar berbagai kendala yang ada, pendekatan kesejarahan ini menawarkan berbagai peluang untuk pengembangan ilmu psikologi, maupun untuk memecahkan berbagai masalah yang tidak bisa dilakukan oleh metode penelitian konvensional (McGuire, 1976; Babbie, 2008). Berbagai bidang dalam psikologi sebagaimana telah ditunjukkan Simonton (2003) memiliki berbagai penelitian yang telah menggunakan metode ini dan menghasilkan karya besar.

\section{Daftar Pustaka}

Abidin, Z. (2006). Pendekatan Kualitatif Pada Skripsi Mahasiswa Psikologi Undip Tahun 2006. Jurnal Psikologi Universitas Diponegoro, 3 (2).

https://doi.org/10.14710/jpu.3.2.26\%20$\% 2036$

Afiatin, T. (1997). Kontroversi Pendekatan Kuantitatif Vs Pendekatan Kualitatif Dalam Penelitian Psikologi. Buletin Psikologi, 5 (1). 10.22146/bpsi.13536

Anderson, C.A. \& Anderson, D.C. (1984). Ambient temperature and violent crime: Tests of the linear and curvilinear hypotheses. J. Pers. Soc. Psychol. 46:91-97. 10.1037//00223514.46.1.91

Babbie, E. (2008). The Basics of Social Research. California: Thomson Wadsworth.

Boor, M. (1981). Effects of United States presidential elections on suicide and other causes of death. American Sociological Review, 46, 61618. https://doi.org/10.2307/2094942 
Boor, M., \& Fleming, J.A. (1984). Presidential election effects on suicide and mortality levels are independent of unemployment rates. American Sociological Review, 49, 706-7. https://doi.org/10.2307/2095427

Bound, M. G. (2014). Nation-State Personality Theory: A Qualitative Comparative Historical Analysis of Russian Behavior, during Social/ Political Transition. Disertasi. Nova Southeastern University

Castillo, J. L. (2011). A Comparative Historical Analysis of Post-War Moral Panics and the Construction of Youth From 1938 to 2011. Disertasi. Florida: University of South Florida.

Cervenka, H. L. (1997). A Comparative Study Of The Development Of Educational Psychology In China And America. Disertasi. Virginia: West Virginia University.

Davis, D. W. (2003). Al-Qaeda and The Phinehas Priesthood Terrorist Groups with A Common Enemy and Similar Justifications for Terror Tactics. Disertasi. Texas A\&M University.

DellaMattera, J. N. M. (2006). A Historical Comparative Analysis Of Preschool Policy Frameworks. Disertasi. Maine: The University of Maine.

Doty, R. M., Peterson, B. E. \& Winter, D.G. (1991). Threat and authoritarianism in the United States, 1978-1987. J. Pers. Soc. Psychol. 61: 629-40. https://doi.org/10.1037/00223514.61.4.629

Elms, A. C. (1988). Freud as Leonardo: why the first psychobiography went wrong. J. Pers. 56:19-40. https://doi.org/10.1111/j.14676494.1988.tb00461.x

Elms, A. C. (1994). Uncovering Lives: The Uneasy Alliance of Biography and Psychology. New York: Oxford University Press.

Galton, F. (1869). Hereditary Genius: An Inquiry into Its Laws and Consequences. London: Macmillan.

Grush, J. E. (1980). Impact of candidate expenditures, regionality, and prior outcomes on the 1976 Democratic presidential primaries. J. Pers. Soc. Psychol. 38:337-47. https://doi.org/10.1037/00223514.38.2.337

James, W. (1880). Great men, great thoughts, and the environment. Atl. Mon. 46:441-59.

Janis, I. L. (1982). Groupthink: Psychological Studies of Policy Decisions and Fiascoes. Boston: Houghton Mifflin.349 pp. 2nd ed.

Kemp, S. \& Strongman, K. T. (1995). Anger Theory and Management: A Historical Analysis. The American Journal of Psychology, Vol. 108, No.
3 (Autumn, 1995), pp. 397-417. https://doi.org/10.2307/1422897

Lange, M. (2013). Comparative-historical methods. London, : SAGE Publications Ltd. https://doi.org/10.4135/9781473914223

Mahoney, J. \& Rueschemeyer, D. (2003). Comparative-historical analysis: achievements and agendas. Dalam Mahoney, J. \& Rueschemeyer, D. (ed). Comparative Historical Analysis in the Social Sciences. Cambridge: Cambridge University Press.

McCann S. J. H. (1999). Threatening times and fluctuations in American church memberships. Pers. Soc. Psychol. Bull. 25:325-36.

https://doi.org/10.1177/0146167299025 003005

McClelland, D. C. (1961). The Achieving Society. Princeton, N. J.: Van Nostrand.

McGuire, W. J. (1976). Historical comparisons: Testing psychological hypotheses with cross-era data. International Journal of Psychology, vol. 11, no 3, 161-183. https://doi.org/10.1080/0020759760824 7356

Miller, T.Q., Heath, L., Moican, J.R. \& Dugoni, B.L. (1991). Imitative violence in the real world: a reanalysis of homicide rates following championship prize fights. Aggress. Behav. 17:121-34. https://doi.org/10.1002/10982337(1991)17:3<121::AID-

AB2480170302>3.0.CO;2-U

Neisser, U. (1981). John Dean's memory: a case study. Cognition 9:1-22. https://doi.org/10.1016/00100277(81)90011-1

Neuman, W. L. (2007). Basics of Social Research, Qualitative and Quantitative Approaches. Boston: Pearson Education.

Phillips D. P. (1986). Natural experiments on the effects of mass media violence on fatal aggression: strength and weakness of a new approach. In Berkowitz, L. (Ed.). Advances in Experimental Social Psychology, 19:207- 50. New York: Academic.

Phillips, D. P. \& Hensley, J. E. (1984). When violence is rewarded or punished: the impact of mass media stories on homicide. J. Commun. 343:101-16. https://doi.org/10.1111/j.14602466.1984.tb02178.x

Rollins, M. (2017). Psychopathy and Narcoterrorism: A Comparative Historical

Analysis Of Pablo Escobar And "El Chapo" Guzman. Thesis. California: California Baptist University. 
Simonton DK. 1998c. Historiometric methods in social psychology. Eur. Rev. Soc. Psychol. 9:267-93.

https://doi.org/10.1080/1479277984300 0108

Simonton, D. K. (2003). Qualitative And Quantitative Analyses Of Historical Data. Annu. Rev. Psychol. 2003.25 54:617-40. https://doi.org/10.1146/annurev.psych.54 .101601 .145034

Skocpol, T. And Somers, M. (1980). The uses of comparative history in macrosocial inquiry. Comparative Studies in Society and History. 22 174. https://doi.org/10.1017/S0010417500009 282

Somantri, G. R. (2005). Memahami Metode Kualitatif. Makara Sosial Humaniora, 9 (2): 57-65. https://doi.org/10.7454/mssh.v9i2.122

Suedfeld, P. \& Bluck, S. (1993). Changes in integrative complexity accompanying significant life events: historical evidence. J. Pers. Soc. Psychol. 64:124-30. https://doi.org/10.1037/00223514.64.1.124

Terman L. M. (1917). The intelligence quotient of Francis Galton in childhood. Am. J. Psychol.
28:209-15. https://doi.org/10.2307/1413721

Thorndike E. L. (1936). The relation between intellect and morality in rulers. Am. J. Sociol. 42:321-34. https://doi.org/10.1086/217430

Tilly, C. (1984). Big Structures, Large Processes, Huge Comparisons. New York:Russell Sage Foundation.

Triplett, N. (1898). The dynamogenic factors in pacemaking and competition. Am. J. Psychol. 9:507-33. https://doi.org/10.2307/1412188

Winter, D. G. (1993). Power, affiliation, and war: three tests of a motivational model. J. Pers. Soc. Psychol. 65:532-45. https://doi.org/10.1037/00223514.65.3.532

Woods FA. (1906). Mental and Moral Heredity in Royalty. New York: Holt.

Yuginovich, T. (2000). More than time and place: Using historical comparative research as a tool for nursing. International Journal of Nursing Practice 2000; 6: 70-75. https://doi.org/10.1046/j.1440172x.2000.00183.x 